\title{
LANSKAP LINGUISTIK BAHASA TULIS DI RUANG PUBLIK DAN UPAYA PENCEGAHAN PENULARAN VIRUS KORONA
}

\author{
Oleh \\ Oktavianus \\ oktavianus@hum.unand.ac.id \\ Fakultas Ilmu Budaya \\ Universitas Andalas \\ Padang
}

\begin{abstract}
ABSTRAK
Tulisan ini merupakan suatu upaya untuk mengkaji bentangan bahasa tulis di ruang publik dalam upaya pencegahan virus korona. Ruang publik adalah temat-tempat di mana anggota masyarakat berkumpul bersama, berinteraksi, dan berkomunikasi seperti di sekolah, tempat ibadah, pasar, jalanjalan umum, rumah sakit, bandar udara, dan di kenderaan-kendaraan umum. Kajian difokuskan kepada disain dan fungsi bahasa tulis di ruang publik. Data untuk keperluan kajian ini diambilkan dari penggunaan bahasa tulis yang terkait dengan virus korona yang ditempatkan pada baliho dan spanduk. Kajian dilakukan dari perspektif pendekatan lanskap linguistik dan analisis wacana. Hasil kajian menunjukkan bahwa bahasa di ruang publik sangat dinamis dan memiliki keberagaman disain. Dari segi penggunaan tanda, bentangan bahasa di ruang publik adalah kombinasi antara bentuk-bentuk lingual dan bentuk nonlingual dengan rancangan dan tata letak yang menarik. Dari segi fungsi, bahasa tulis di ruang publik yang dipajang dalam bentuk baliho dan spanduk memiliki fungsi sebagai media untuk mendidik masyarakat untuk menghindari penularan virus korona.
\end{abstract}

Kata kunci: bahasa, ruang publik, lanskap linguistik, virus korona dan teks.

\section{ABSTRACT}

\section{LINGUISTIC LANDSCAPE OF WRITTEN LANGUAGE AT PUBLIC SPACES AND EFFORTS TO PREVENT THE TRANSMISSION OF THE CORONA VIRUS}

This article is an attempt to study the landscape of written languages at public spaces in order to prevent the transmission of corona virus. Public spaces are the spaces where people gather, interact and communicate to each other such as at school, the worship places, the markets, public streets, hospitals, air ports, and public transportations. The study is focused on the the designs and functions of languages at public spaces. The data for this study are collected from the use of written languages related to corona virus as displayed on billboards and banners. The study is conducted by applying linguistic landscape and discourse analysis approach. The results of the study indicate that the landscape of the languages of public spaces used to prevent coronavirus are very dynamic and have various designs. In terms of the use of signs, the landscapes of the languages at public spaces are the combination among linguistic and nonlinguistic signs with an attractive design and layout. In terms of functions, the languages at public places which are displayed in the billboards and banners have the function to educate people to avoid the transmission of coronavirus.

Key words: the language, public space, linguistic landscape, corona virus and text. 


\section{Pendahuluan}

Ketika berada di ruang-ruang publik seperti di pasar, jalan-jalan umum, bandar udara, sekolah, tempat-tempat ibadah, dan tempat-tempat umum lainnya, kita dapat mengamati kompleksitas kehidupan masyarakat dengan segala dinamikanya. Dalam dinamika kehidupan yang demikian itu, bahasa memiliki fungsi yang sangat penting. Dari hasil pengamatan di lapangan, bahasa lisan yang digunakan dalam berinteraksi dan berkomunikasi ternyata memiliki keterbatasan pula. Bahasa lisan tidak sepenuhnya bisa digunakan dalam menginformasikan sesuatu dan membentuk perilaku penutur dan pendukung bahasa tersebut. Kehadiran bahasa tulis dengan beragam disain diperlukan di ruang publik. Masyarakat yang berada di ruang-ruang publik sangat terbantu dengan keberadaan bahasa tulis. Mereka dapat mengakses informasi yang disampaikan secara berulang-ulang karena bahasa tulis yang melekat pada spanduk dan baliho ditempatkan pada suatu kawasan untuk jangka waktu tertentu dan bahkan ada yang bersifat permanen.

Kemunculan virus korona pada akhir tahun 2019 yang ditetapkan sebagai pandemi oleh WHO berdampak sistemik bagi keseluruhan kehidupan manusia di seluruh dunia. Virus korona mempengaruhi perekonomian masyarakat, kehidupan dan aktivitas keagamaan. Virus korona bahkan juga membawa dampak psikologis yang luar biasa kepada masyarakat. Lebih dari itu, virus korona bahkan juga dijadikan komoditas politik bagi sebagian orang. Situasi pada saat ini menjadi rumit.

Dari sisi penggunaan bahasa tulis di ruang publik, keberadaan virus korona telah pula menggeser dan bahkan mengubah penggunaan bahasa di ruang publik. Kita dengan mudah menemukan tulisan-tulisan berisi himbauan memakai masker, mencuci tangan, dan menjaga jarak di ruang-ruang publik. Di kantor-kantor pemerintah dan di tempat-tempat umum, kita menemukan tulisan KAWASAN WAJIB PAKAI MASKER, CUCI TANGAN, dan JAGA JARAK. Kursi-kursi tempat duduk bahkan diberi penanda jarak duduk antara satu orang dengan orang lainnya. Penggunaan bahasa yang demikian itu adalah cerminan realitas sosial budaya masyarakat penutur bahasa. Chaika (1989) menyatakan bahwa bahasa adalah cerminan berbagai aspek sosial penuturnya. Di samping itu, bahasa tulis di ruang publik memiliki peran yang sangat penting dalam membentuk dan mengontrol perilaku penutur atau pendukung bahasa tersebut (Oktavianus, 2019). Berikut ini adalah salah satu contoh himbauan pencegahan virus korona yang dipajang di salah satu toko pusat oleh-oleh di Kota Padang. 


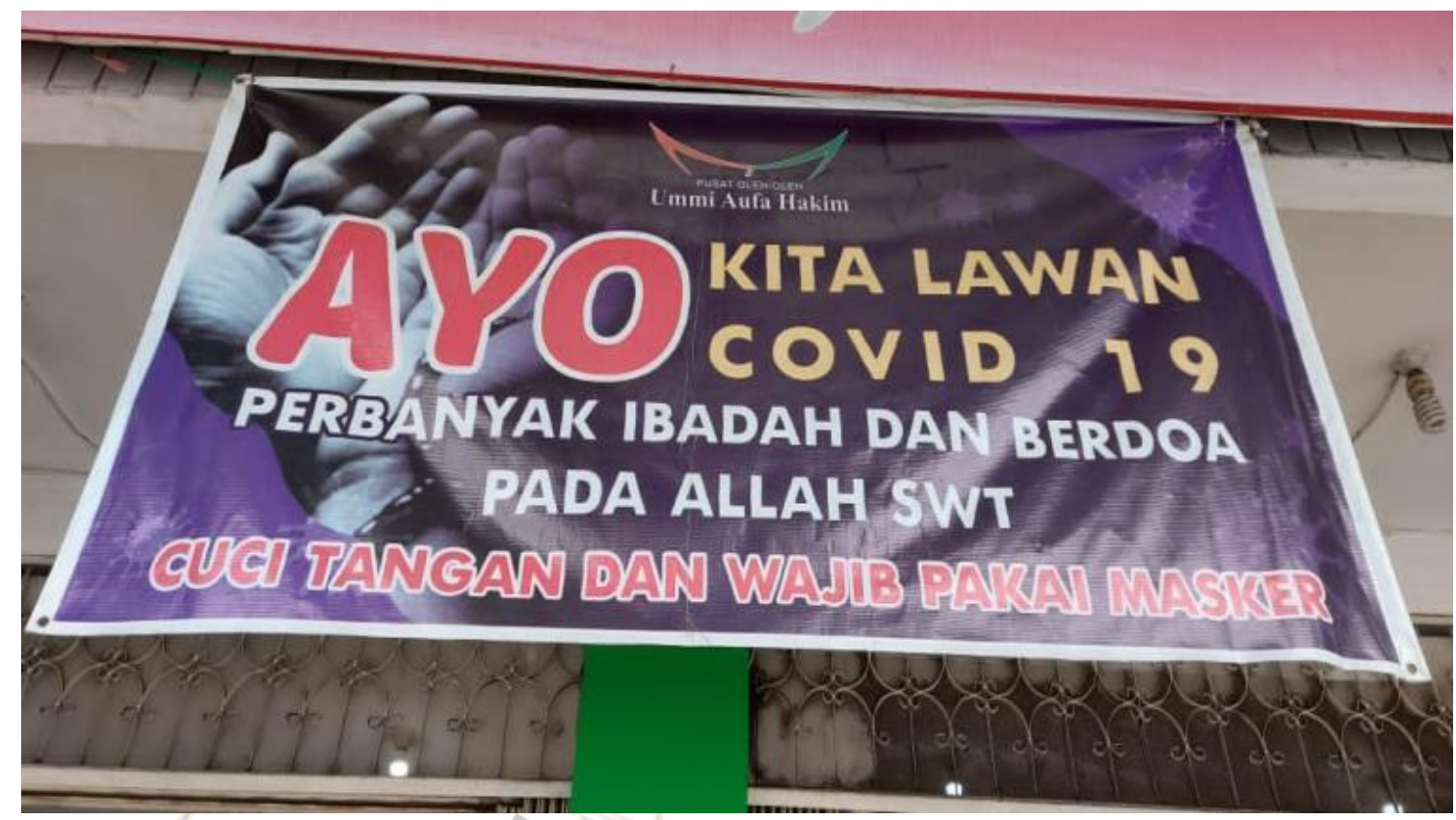

Sumber Foto: Ajakan mewaspadai Covid-19 (Dok. Oktavianus, 2021).

Disain bentangan bahasa tulis di ruang publik dalam upaya pencegahan virus korona sebagaimana ditampilkan pada gambar di atas, efektifitas dan ketersampaian pesan yang terkandung di dalamnya menjadi menarik untuk dikaji. Sehubungan dengan itu, tulisan singkat ini merupakan suatu upaya untuk menelaah penggunaan bahasa tulis di ruang publik untuk mencegah penularan virus korona. Kajian ini diharapkan dapat memberikan sumbangan kepada masyarakat dalam mengatasi salah satu masalah besar yang kita hadapi saat ini yaitu penularan virus korona.

\section{Metode}

Kajian ini menggunakan pendekatan lanskap linguistik yaitu analisis bentangan bahasa di ruang publik. Sub teori yang digunakan adalah pendekatan analisis wacana atau teks. Analisis lanskap linguistik bahasa di ruang publik dapat saja menerapkan satu atau lebih teori linguistik yang dianggap relevan sesuai dengan ketersediaan data. Data untuk keperluan kajian ini diambilkan dari penggunaan bahasa tulis di ruang-ruang publik yang ditempatkan pada baliho dan spanduk. Analisis data dilakukan melalui diskusi dengan narasumber dan wawancara dengan masyarakat. Diskusi dan wawancara dilakukan untuk mencermati sejauh mana mereka memiliki kepedualian terhadap bahasa yang digunakan untuk pemcegahan virus korona. Analisis data juga dilakukan dengan merujuk kepada metode padan dan metode agih yang dikemukakan oleh Sudaryanto (2018). 


\section{Lanskap Linguistik Bahasa Ruang Publik dan Upaya Pencegahan Virus Korona}

Lanskap linguistik adalah suatu pendekatan dalam kajian bahasa. Gorter (2006c:1) mengemukakan bahwa lanskap linguistik dalah suatu pendekatan dalam kajian linguistik untuk menganalisis situasi kebahasaan atau bentangan bahasa pada suatu kawasan. Pengertian lainnya tentang lanskap linguistik dapat pula dicermati pada kutipan berikut ini.

The language of public road signs, advertising billboards, street names, place names, commercial shop signs, and public signs on government buildings combines to form the linguistic landscape of a given territory, region or urban agglomeration (Landry and Bourhis, 1997:25)

Dari kutipan di atas, kita dapat mengatakan bahwa warna-warni bahasa pada jalan umum, papan iklan, nama-nama jalan, nama-nama tempat, nama-nama toko, dan label-label lainnya yang diperuntukkan bagi masyarakat yang dilekatkan pada gedung perkantoran membentuk suatu bentangan bahasa yang disebut dengan lanskap linguistik. Dengan kata lain, lanskap linguistik adalah bentangan bahasa pada suatu kawasan.

Dalam menganalisis bentangan bahasa yang mewadahi suatu realitas seperti bahasa-bahasa yang menggambarkan segala hal terkait dengan virus korona, pendekatan lanskap linguistik dapat saja menerapkan satu atau lebih teori atau sub teori linguistik yang dianggap relevan. Untuk menelaah bentangan bahasa tulis di ruang publik yang menjadi focus kajian ini, kajian ini mengkombinasikan pendekatan lanskap linguistik dengan teori analisis wacana.

Bahasa-bahasa yang didisain sedemikian rupa yang dilekatkan pada spanduk dan baliho dapat dianggap sebagai sebuah teks. Bahasa-bahasa yang demikian itu dirancang dengan menggabungkan sejumlah tanda baik tanda linguistik maupun tanda non linguistik berupa gambar dan ilustrasi. Disain huruf, pewarnaan dan tata letak menjadi ciri tersendiri bahasa-bahasa tulis yang ditempatkan di ruang publik. Berikut ini adalah salah satu contoh baliho yang berisi himbauan pencegahan virus korona. 


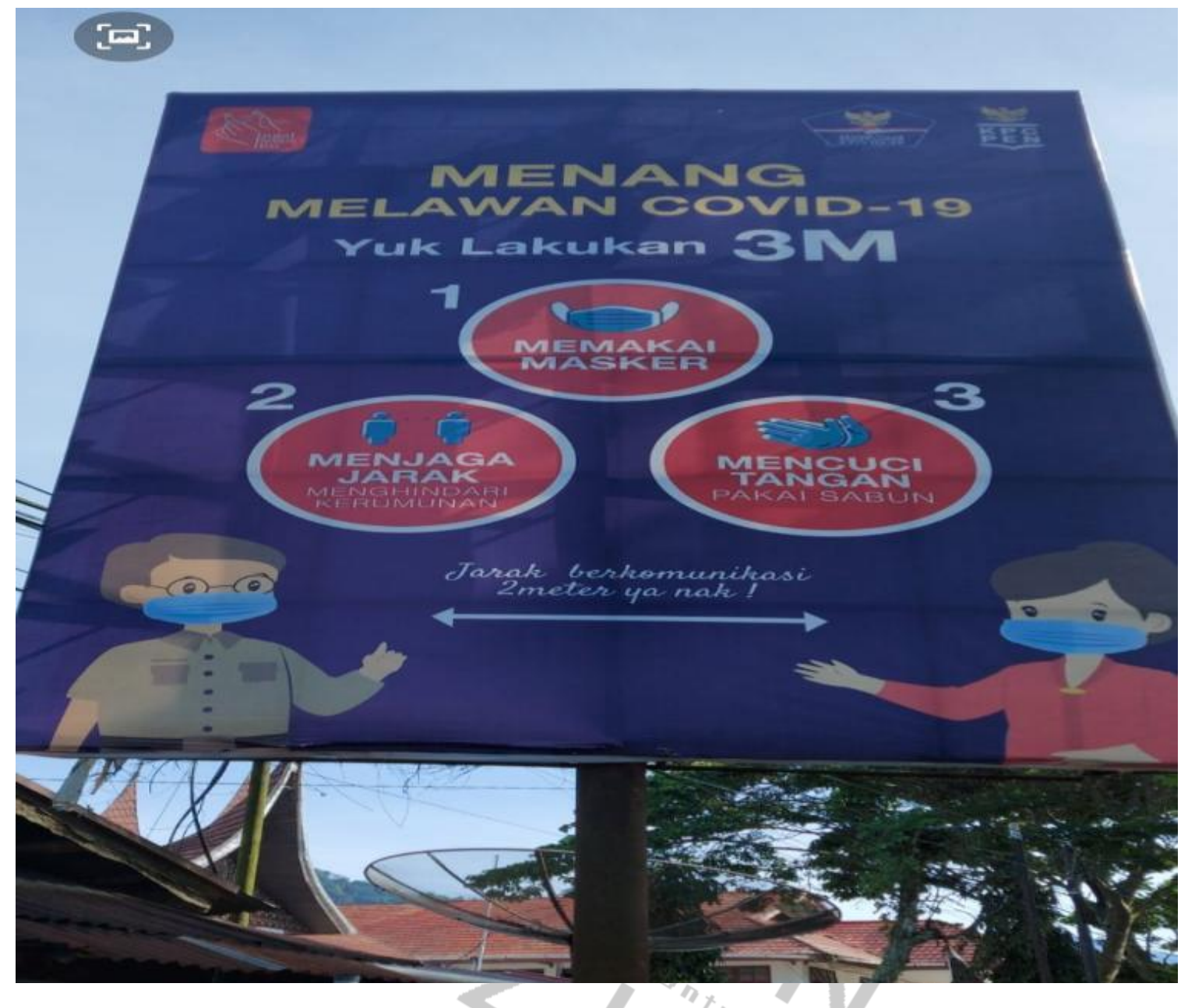

Sumber : Baliho ajakan mewaspadai virus korona di salah satu ruas jalan Kota Padang (Dok. Oktavianus, 2021).

Gambar di atas adalah salah satu baliho yang dibuat oleh pemerintah dalam upaya mewaspadai dan mencegah transmisi virus korona. Kemasan bahasa pada baliho tersebut merupakan upaya untuk mengajak masyarakat mewaspadai dan mengantisipasi penularan virus korona. Tata letak dan disain bahasa pada baliho tersebut dianggap efektif dalam mengedukasi masyarakat mewaspadai virus korona (Oktavianus, 2021). Ketua Bidang Perubahan Perilaku Satgas Covid-19 mengeluarkan himbauan agar masyarakat mematuhi 3 M, yaitu Memakai Masker, Mencuci Tangan dan Menjaga Jarak. Slogan $3 \mathrm{M}$ ini diharapkan mampu mengurangi dan bahkan mengatasi transmisi virus korona dari orang ke orang. Memakai masker dan menjaga jarak dianggap dapat menghambat percikan droplet yang mungkin dibawa atau diterbangkan angin pada saat seseorang berbicara dengan orang lainnya. Mencuci tangan dilakukan agar tangan tetap selalu bersih dari kemungkinan-kemungkinan melekatnya virus korona yang bisa jadi menempel di benda-benda yang tersentuh atau dipegang dalam melakukan berbagai aktivitas sehari-hari. Baliho tersebut berisi ajakan melawan virus korona dengan tiga himbauan utama sebagai berikut. 
(1) MEMAKAI MASKER

(2) MENJAGA JARAK

(3) MENCUCI TANGAN

Baliho tersebut sepertinya adalah dialog antara orang tua dengan anaknya. Ini ditunjukkan pula dengan penggunaan kalimat sebagai berikut.

(4) Jarak berkomunikasi 2 meter ya nak !

Kalimat (4) di atas dapat dianggap sebagai ajakan yang bersifat persuasif dan terkesan lebih santun. Penggunaan kata sapaan atau sebutan nak membuat kalimat tersebut terasa lebih santun dan membangun kedekatan antara orang tua dengan anak. Penggunaan kata sapaan tertentu sesuai dengan konteks pertuturan membuat sebuah ujaran terasa lebih santun (Oktavianus dan Ike Revita, 2013).

Dari aspek lanskap linguistik, disain bahasa yang digunakan sudah dirancang sedemikian rupa sehingga pesan diharapkan dapat ditangkap dan dipahami oleh masyarakat dengan mudah.

Tulisan MENANG MELAWAN COVID-19 dibuat dengan huruf besar dengan latar warna kuning. Yuk lakukan didisain dengan gabungan antara huruf kecil, sedangkan 3M didisain dengan huruf besar dengan latar warna putih. Pesan inti MEMAKAI MASKER, MENJAGA JARAK dan MENCUCI TANGAN di buat dengan huruf besar berwarna putih dengan latar berwarna merah.

Crystal (1998:12) mengemukakan bahwa salah satu fungsi bahasa adalah sebagai alat pengontrol realitas. Dalam pengertian yang lebih luas, dengan bahasa kita dapat mengubah suatu keadaan. Bahasa yang digunakan pada baliho di atas adalâh untuk mengubah suatu keadaan atau menghindari suatu situasi yaitu terhindar dari virus korona. Suatu bahasa akan dapat menjalankan fungsinya sebagai alat untuk mengubah keadaan atau suatu situasi apabila pesan yang terkandung di dalam bahasa itu dapat dicerna dengan baik oleh para penuturnya.

Bila dicermati baliho di atas, disain grafis huruf-huruf yang digunakan dan pewarnaan cukup memudahkan bagi publik untuk menangkap pesan yang terkandung pada baliho tersebut. Pemahaman terhadap pesan yang disampaikan menjadi lebih mudah dan menarik dengan hadirnya tanda-tanda nonlingual berupa gambar orang memakai masker, panah sebagai ilustrasi jarak berkomunikasi, gambar masker dan ilustrasi mencuci tangan. Namun demikian, dari diskusi dan wawancara di lapangan, letak baliho yang begitu tinggi sedikit mengurangi arti baliho tersebut karena masyarakat harus menyediakan waktu khusus untuk mencermatinya.

Selain dari baliho yang ditempatkan pada jalan-jalan umum sebagaimana terlihat pada baliho di atas, penggunaan bahasa di ruang publik untuk mewaspadai dan mencegah virus korona juga ditemukan pada pintu masuk toko. Berikut adalah salah satu contoh pengggunaan bahasa sebagai ajakan atau peringatan untuk mewaspadai virus korona. 


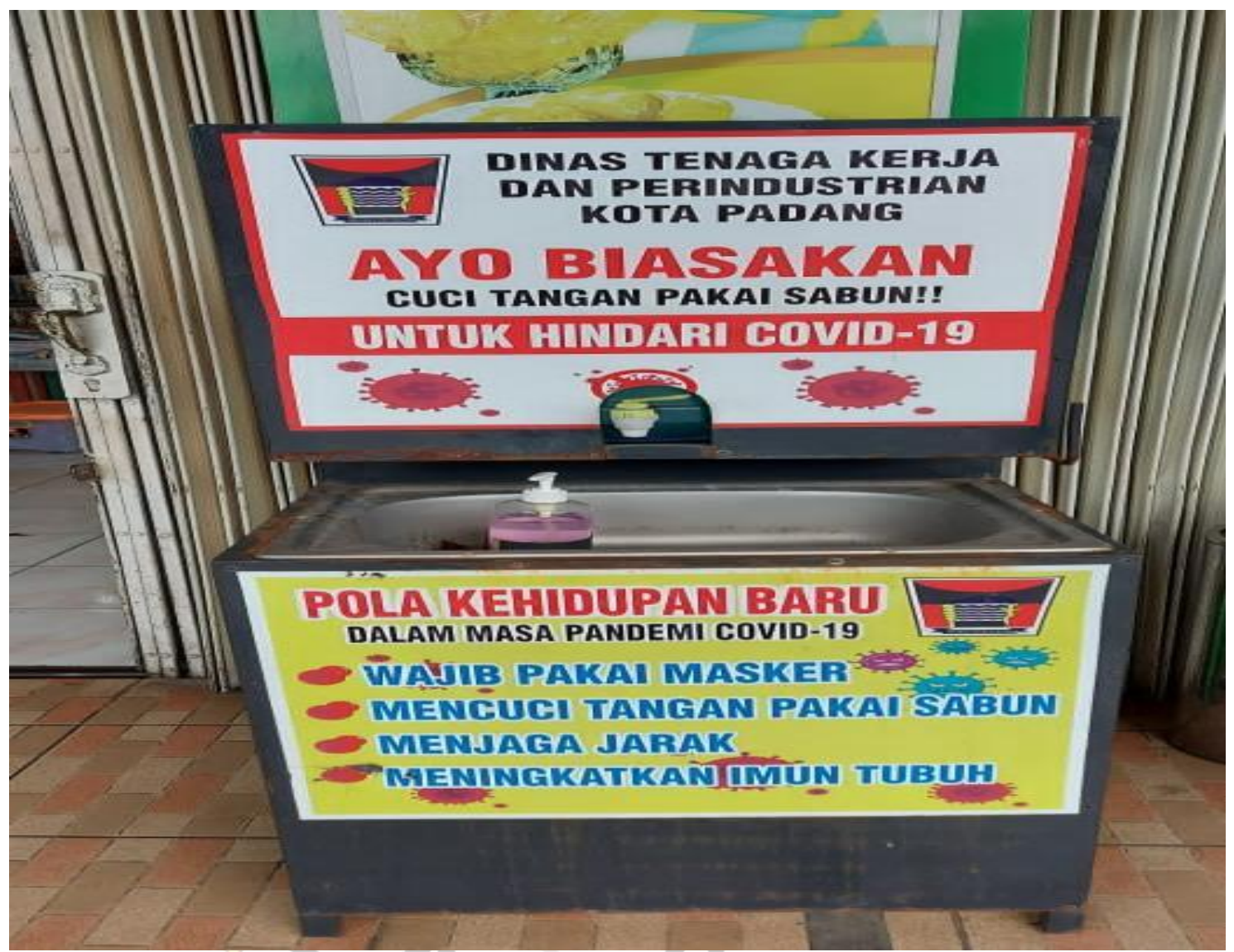

Sumber: Penggunaan bahasa bagi pencegahan virus korona di Toko Aufa Hakim Padang.

(Dok. Oktavianus, 2021).

Gambar di atas adalah penggunaan bahasa untuk mewaspadai dan menghindari virus korona yang dibuat oleh Dinas Tenaga Kerja dan Perindustrian Kota Padang. Ada dua kategori penggunaan bahasa pada gambar tersebut yaitu (1) ajakan untuk membiasakan diri mencuci tangan; dan (2) deskripsi kehidupan pada masa normal baru. Ajakan membiasakan diri mencuci tangan ditulis dengan huruf besar berwarna merah, yaitu AYO BIASAKAN. Kombinasi bentuk lingual yang menjadi ikutannya ditulis dengan huruf besar yang agak dikecilkan dan diberi warna hitam dan dikuti oleh dua tanda seru. Tulisan UNTUK HINDARI COVID-19 ditulis dengan huruf besar dan diberi warna putih dengan latar warna merah. Perbedaan disain huruf dengan warna dan latar yang berbeda-beda dimaksudkan agar pesan yang disampaikan dapat dibaca dan dipahami dengan mudah. Di samping itu, dari aspek sosiolinguistik, ragam bahasa yang digunakan adalah ragam informal. Hal itu ditandai dengan pelesapan prefik me- pada kata hindari. Dengan menerapkan metode agih dan teknik ganti sebagaimana dikemukakan oleh Sudaryanto (2018), bentuk-bentuk tersebut dapat muncul sebagai berikut. 
(5) Untuk hindari covid-19

(5a) Untuk menghindari covid-19

Konstruksi (5a) tidak muncul karena penggalan kalimat (5) seperti sudah dianggap dapat menyampaikan maksud. Kemudian, secara keseluruhan kalimat pada bagian pertama gambar tersebut dapat dikategorikan berisi ajakan dan perintah. Uraiannya adalah sebagai berikut.

(6) Ayo biasakan

(7) Cuci tangan pakai sabun!!

(8) Untuk hindari covid-19

Perbedaan disain grafis huruf dan pewarnaan membuat kalimat dan bagian-bagiannya menjadi memiliki 3 pesan utama yaitu membiasakan diri, mencuci tangan dan untuk menghindari covid-19. Contoh (6)-(8) di atas dapat saja dijadikan menjadi sebuah kalimat lengkap sehingga muncul kalimat dengan konstruksi sintaksis sebagai berikut.

(9) Ayo biasakan mencuci tangan dengan sabun untuk menghindari covid-19.

Istilah covid-19 itu sendiri adalah bahasa Inggris dengan bentuk lengkapnya corona virus disease yang ditemukan pada tahun 2019. Istilah virus korona lebih mudah dipahami sebagian masyarakat dibandingkan dengan sebutan covid-19. Oleh sebab itu, kalimat (9) dapat saja muncul sebagai berikut.

(10) Ayo biasakan mencuci tangan pakai sabun untuk menghindari virus korona

Kerapian pemakaian bahasa pada baliho atau gambar seperti di atas dapat membantu penyampaian pesan dengan lugas dan tidak membingungkan pembaca. Ini adalah bagian dari disiplin berbahasa.

Selanjutnya, pada bagian kedua gambar di atas adalah deskripsi kehidupan pada masa normal baru. Istilah Normal Baru berasal dari terjemahan bahasa Inggris New Normal. Normal Baru adalah sebuah situasi yang terbentuk dalam menghadapi virus korona di mana hal-hal yang sebelumnya kurang atau tidak lazim, sekarang harus menjadi suatu kebiasaan. Gambaran kehidupan pada masa Normal Baru tersebut setidaknya tercermin dari bentuk-bentuk bahasa sebagai berikut.

(11) Wajib pakai masker

(12) Mencuci tangan pakai sabun

(13) Menjaga jarak

(14) Meningkatkan imun tubuh 
Sebagai bagian dari bahasa yang ditempatkan diruang publik, bentuk-bentuk lingual pada (11)-(14) di atas ditulis dengan huruf besar. Ini dimaksudkan agar pesan yang disampaikan mudah dibaca dan dipahami. Suatu hal yang menarik pada kedua gambar tersebut adalah penempatan gambar virus korona di sela-sela tulisan tersebut. Penampatan gambar visual korona tentu saja diharapkan dapat menciptakan efektifitas penyampaian pesan kepada publik.

Penampatan logo pemerintah Kota Padang pada sudut kiri dan kanan atas gambar tersebut serta tulisan Dinas Tenaga Kerja dan Perindustrian Kota Padang menambah bentangan bahasa pada kedua gambar tersebut. Pesan yang dapat ditangkap di sini adalah adanya kepedulian pemerintah dalam menanggulangi virus korona. Label Dinas Tenaga Kerja dan Perindustrian ditempatkan pada bagian atas gambar tersebut karena himbauan kewaspadaan terhadap virus korona dan pola-pola kehidupan pada masa normal baru ditempatkan pada toko oleh-oleh dan barang-barang kerajinan yang berada di bawah lingkup kerja Dinas Tenaga Kerja dan Perindustrian.

Himbauan untuk pencegahan dan mewaspadai virus korona ditemukan pada banyak tempat di ruang-ruang publik. Selain di tempat-tempat strategis seperti jalan-jalan umum, toko dan tempattempat lainnya, himbauan untuk mewaspadai virus korona dan panduan untuk menghadapi kehidupan pada masa normal baru juga ditemukan di lembaga-lembaga pendidikan. Berikut ini adalah salah satu contoh banner berisi himbauan mewaspadai virus korona dan panduan pola hidup pada masa normal baru yang ditemukan di Fakultas Ilmu Budaya Universitas Andalas Padang. 


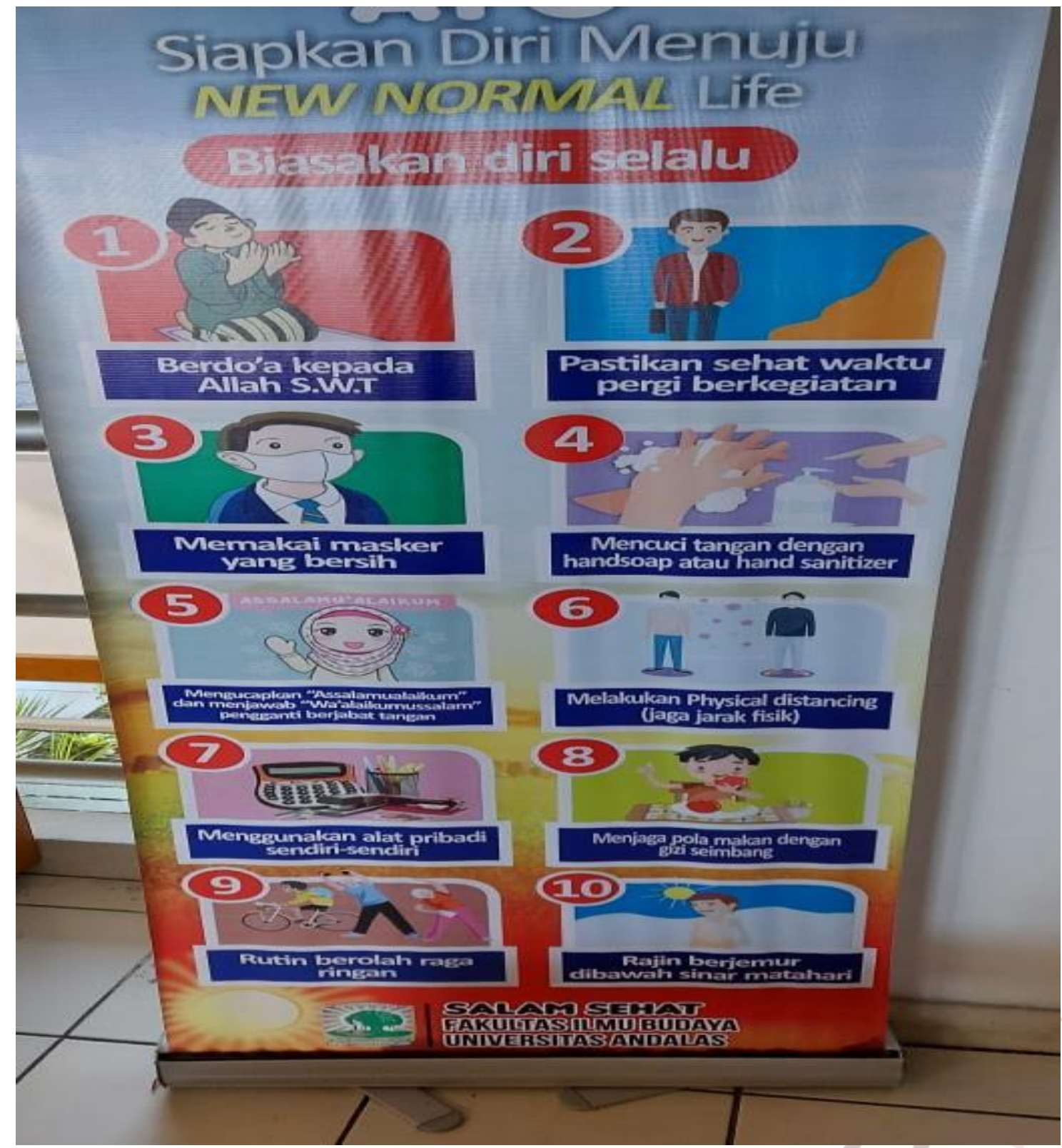

Sumber : Foto banner pencegahan virus korona di Fakultas Ilmu Budaya

(Dok. Oktavianus, 2021).

Teks pada gambar di atas dibentuk dengan merangkai 10 kalimat dalam sebuah banner. Istilah teks itu sendiri oleh Halliday (1980) adalah konstruksi bahasa baik dalam bentuk lisan maupun tulisan yang memiliki kepaduan semantis. Shiffrin (1994:1) menyatakan bahwa teks adalah bahasa yang sedang menjalankan fungsinya. Fungsi yang sedang dijalankan oleh kumpulan kalimat pada gambar di atas adalah pesan pencegahan dan penangulangan virus korona. Di samping itu, teks dapat juga disebut sebagai wujud kongret dari sebuah wacana (Oktavianus, 2006). Pada gambar di atas, wacana pencegahan virus korona diwujudkan melalui salah satu bentuk teks yang didisain seperti banner tersebut sehingga banner itu berwujud sebagai bentangan bahasa yang ditata sedemikian rupa melalui 
kombinasi bentuk-bentuk lingual dan bentuk non lingual yang dilengkapi dengan disain grafis hurufhuruf dan pewarnaan.

Konstruksi kalimat pada banner di atas diawali dengan pembukaan yaitu Siapkan diri menuju NEW NORMAL Life. Bagian awal yang berfungsi sebagai pembuka teks didisain dengan menggunakan campur kode antara bahasa Indonesia dangan bahasa Inggris. Frasa NEW NORMAL ditulis dengan huruf besar dan diberi warna kuning. Disain seperti ini adalah sebagai penanda bahwa yang menjadi titik fokus adalah pola-pola kehidupan pada masa normal baru. Kesepuluh kalimat yang menjadi ikutan teks tersebut adalah sebagai berikut.

(15) A Berdoa kepada Allah SWT.

B Pastikan sehat waktu pergi berkegiatan.

C Memakai masker yang bersih.

D Mencuci tangan dengan handsoap atau hand sanitizer.

E Mengucapkan "assalamualaikum" dan menjawab "alaikum salam" pengganti berjabat tangan.

F Melakukan physical distancing (Jaga jarak fisik)

G Menggunakan alat pribadi sendiri-sendiri

$\mathrm{H} \quad$ Menjaga pola makan dengan gizi seimbang

I Rutin berolah raga ringan

J Rajin berjemur dibawah sinar matahari.

Sebagai sebuah teks yang padu, kesepuluh kalimat di atas memiliki satu kesatuan makna yang utuh yaitu upaya pencegahan virus korona secara terintegrasi agar tidak mudah masuk ke dalam tubuh kita dan tidak pula menular kepada orang lain. Yang dimaksudkan dengan pencegahan secara terintegrasi adalah upaya-upaya pencegahan dari sudut pandang dan pendekatan yang berbeda tetapi memiliki satu kesatuan yaitu berserah diri kepada Allah dengan berdoa, memakai alat pelindung diri seperti masker, menjaga kebersihan yaitu mencuci tangan dengan handsoap dan hand sanitizer, menjaga pola makan untuk meningkatkan imun tubuh, menjaga jarak fisik dalam berkegiatan, berolah raga dan berjemur di bawah matahari adalah dalam rangka meningkatkan imunitas tubuh.

Baliho di atas dirancang sedemikian rupa dengan mengkombinasikan bentuk-bentuk lingual dengan bentuk-bentuk nonlingual berupa gambar. Penempatan gambar dalam bentuk orang berdoa, berolah raga, berangkat kerja, memakai masker, mencuci tangan, dan menjaga jarak dengan aneka warna dan disain membuat banner itu memiliki daya tarik tersendiri dalam mewujudkan suasana bebas virus korona. Di samping itu, teks di atas dapat dianggap sebagai teks yang padat makna karena teks tersebut merupakan sebuah teks besar yang memiliki sub-sub teks dengan makna yang berbedabeda tetapi terintegrasi menjadi satu kesatuan. Bahasa-bahasa yang ditempatkan di ruang publik baik sebagai nama tempat usaha maupun himbauan, ajakan dan slogan dalam bentuk baliho dan spanduk ditata seindah mungkin, mudah dilihat dan dibaca dan bahkan di malam hari dibantu dengan pencahayaan (Oktavianus, Ike Revita dan Khairil Anwar, 2019). 
Virus korona dapat menular dari orang ke orang melalui percikan cairan yang berasal dari orang yang sudah dinyatakan positif tertular virus tersebut. Oleh sebab itu, langkah-langkah pencegahan adalah memakai masker, mencuci tangan dan mejaga jarak sebagaimana dinyatakan pada baliho di atas. Upaya lainnya yang dapat dilakukan adalah melakukan vaksinasi. Berikut ini adalah salah satu contoh spanduk terkait dengan vaksinansi virus korona.

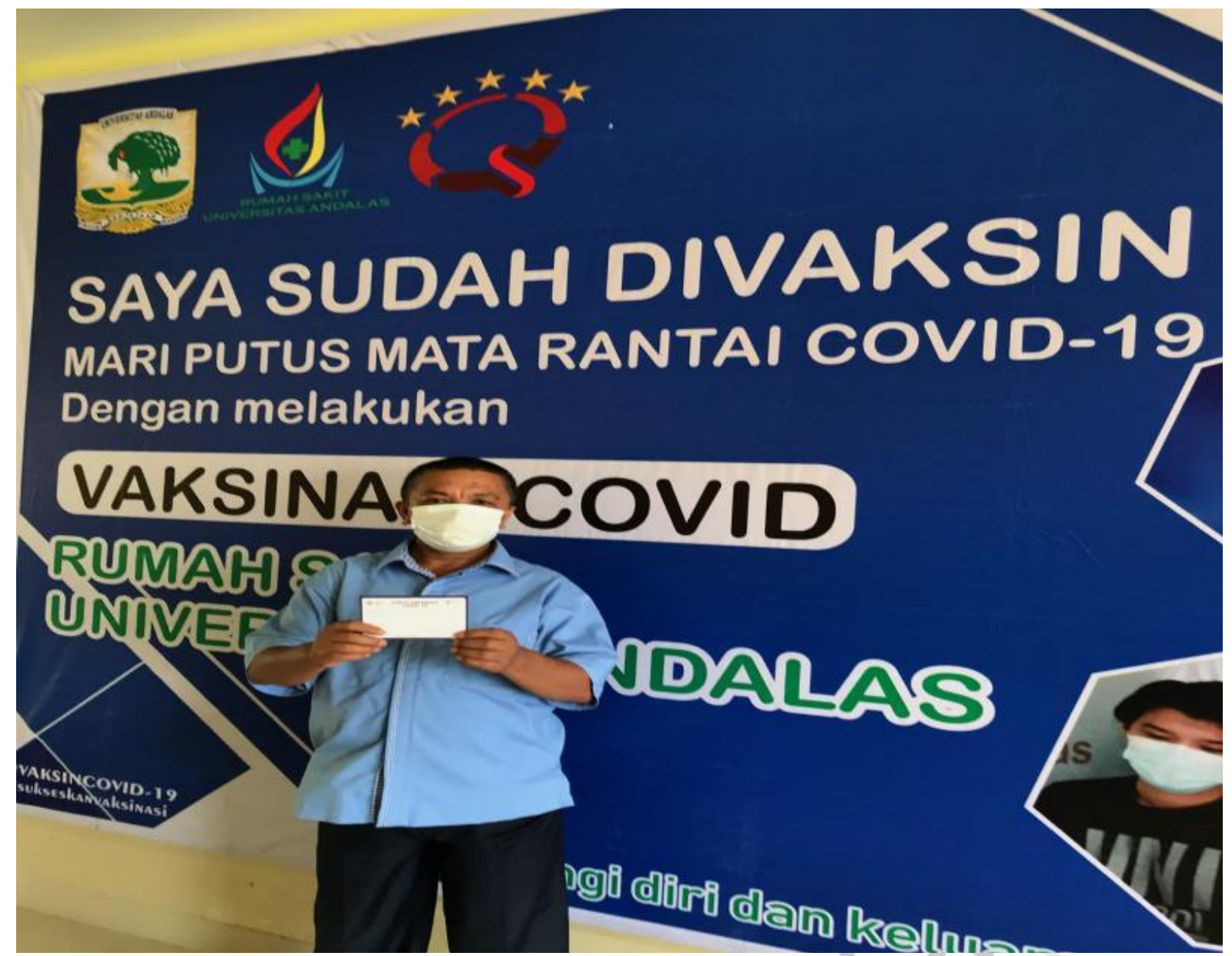

Sumber : Spanduk sebagai latar yang berisi pernyataan sudah divaksin

(Dok. Oktavianus, 2021).

Spanduk di atas dibuat oleh Rumah Sakit Universitas Andalas. Spanduk itu ditempatkan di ruang observasi setelah orang melakukan vaksin. Spanduk itu berisi pernyataan dengan tulisan dibuat dengan huruf besar yang menyatakan SAYA SUDAH DIVAKSIN. Kalimat itu diikuti pula oleh konstruksi MARI PUTUS MATA RANTAI COVID-19 yang ditulis dengan huruf besar tetapi ukuran fontasi hurufnya lebih kecil dibandingkan kalimat di atasnya. Teks di atas secara tersirat mengandung pesan untuk meyakinkan orang lain agar ikut pula divaksin. Sebuah teks tidak muncul begitu saja. Ada peristiwa di balik kemunculan teks tersebut.

Langkah pemerintah untuk melakukan vaksin tampaknya menimbulkan polemik pula di tengah-tengah masyarakat. Ada yang mau divaksin. Ada pula yang merasa enggan dan bahkan tidak 
mau divaksin. Sebagian anggota masyarakat mempertanyakan status vaksin yang akan dipakai apakah vaksin itu baik dan halal untuk sebagian kelompok. Majelis Ulama Indonesia (MUI) melalui Fatwa Nomor: 02 Tahun 2021 tentang vaksin Produk Sinovac yang berasal dari Cina menyatakan bahwa vaksin tersebut baik, suci dan halal bagi umat islam. Pernyataan bahwa SAYA SUDAH DIVAKSIN tersebar secara luas baik melalui baliho maupun pernyataan yang dibuat oleh orang yang sudah divaksin.

Sampai saat ini, upaya pencegahan virus korona belum sepenuhnya berhasil. Hal itu ditunjukkan oleh peningkatan jumlah orang yang tertular virus korona di berbagai wilayah di Indonesia. Sampai tanggal 27 April 2021, total kasus orang tertular virus korona adalah sebanyak 1.651.794 orang (Kompas.com., 27 April 2021). Mengatur perilaku masyarakat tampaknya tidak mudah. Menghindari kerumunan kelihatannya agak sulit. Acara-acara yang sifatnya mengumpulkan orang banyak/ dengan berbagai versi masih tetap saja terjadi. Protokol kesehatan tidak pula sepenuhnya diikuti. Menerapkan pola hidup pada era normal baru belum sepenuhnya menjadi kebiasaan masyarakat. Pemerintah telah memberlakukan Pembatasan Sosial Berskala Besar (PSBB), razia masker, pembuatan baliho, banner dan spaduk berisi kampanye pencegahan virus korona.

\section{Kesimpulan}

Berdasarkan uraian di atas, salah satu upaya yang dapat dilakukan untuk mencegah dan mewaspadai penularan virus korona adalah memberi peringatan, ajakan dan sosialisasi kepada masyarakat tentang langkah-langkah pencegahan transmisi virus korona. Peringatan, ajakan dan himbauan yang dikemas sedemikian rupa ke dalam bentuk baliho, spanduk dan banner merupakan salah satu cara mengedukasi masyarakat yang dianggap tepat karena baliho, banner dan spanduk tersebut dapat diamati setiap saat. Pemaparan bahasa dengan cara demikian dapat membentuk persepsi dan mempengaruhi perilaku masyarakat. Masyarakat dapat menangkap pesan yang disampaikan melalui spanduk, baliho dan banner dengan mudah karena disain dan penulisan pesan dibantu dengan ilustrasi dan gambar sehingga menciptakan daya tarik tersendiri bagi masyarakat.

\section{Referensi}

Chaika, E. (1989). Language: The Social Mirror. New York: New Burry House Publishers.

Crystal, David. (1998). The Cambridge Encyclopedia of Language. Cambridge: Cambridge University Press.

Gorter, Durk. (2006). Linguistic Landscape: New Approaches to Multilingaulism. Toronto: Multilingual Matters Ltd.

Halliday, M.A.K. (1980). Cohesion in English. London: Longman Ltd. 
Landry, Rodrigue \& Richard Y. Bourhis. (1997). "Linguistic Lanscape and Ethnolinguistic Vitality: An Emprical Study". Journal of Language and Social Psychology.

Oktavianus. (2006). Analisis Wacana Lintas Bahasa. Padang: Andalas University Press.

Oktavianus dan Ike Revita. (2013). Kesantunan dalam Bahasa Minangkabau. Padang: Minangkabau Press.

Oktavianus, Ike Revita dan Khairil Anwar. (2019). "Lanskap Linguistik Nilai Budaya pada Rumah Makan Minang”. Jurnal MOZAIK HUMANIORA, Vol 19 (1)-90-108 Tahun 2019.

Oktavianus. (2019). The Roles and Designs of English at Public Places. Prosiding Makalah International Seminar on Linguistics-4 (ISOL-4). Diterbitkan oleh Bereitgestellt von Kangwon National University (100120).

Oktavianus. (2021). "Virus Korona dalam Bahasa Ibu: Sebuah kajian dari Aspek Linguistik". Fakultas Ilmu Budaya Universitas Udayana: Prosiding Seminar Nasional Bahasa Ibu.

Shiffrin, D. (1994). Approahes to Discourse. Cambridge: Blackwell Publisher.

Sudaryanto. (2018). Metode dan Aneka Teknik Analisis Bahasa. Yogyakarta: Sanata Dharma University Press. 